\title{
EVALUATION OF SOME ESSENTIAL OILS FOR CONTROLLING VARROA MITES AND THEIR EFFECTS ON BROOD REARING ACTIVITY IN HONEY BEE COLONIES. El-Hady, A. M. ${ }^{1}$; E. E. Nowar ${ }^{2}$ and M. F. EL-Sheikh ${ }^{3}$ 1-Department of Bee Research, plants Protection Institute, ARC, EL- Doki -Giza. Egypt \\ 2-Department of plant Protection, Faculty of Moshtohor, Benha Univ. 3-Department of plant Protection, Economic Entomology, Faculty of Tanta, Tanta Univ.
}

\begin{abstract}
This study was carried out to assess the efficacy of controlling essential oils i.eThymol, Cinnamon and Anise oils with different concentrations compared to $65 \%$ Formic acid in controlling Varroa destructor mites infesting colonies of Apismellifera during the winter and summer of 2013 season. Randomized complete block design was applied at this study. The apiary was divided into 7 groups ( 3 colonies / group). Three application of the oils. Average of Varroa infestation level before treatment ranged between 21-29 in winter and from 37-47 in summer. The treatments were significantly effective when applied in summer than the winter season and when used at $30 \%$ concentration than those obtained at $15 \%$ concentration compared to the control treatment. Average efficacies percentage ranged between $80.95 \%$ (Cinnamon oil $30 \%$ ) to 86.99 (Thymol 30\%) in winter and from $67.46 \%$ (Thymol $30 \%$ ) to $82.16 \%$ (Cinnamon $30 \%$ ). Thymol oil was the best in winter, however, Cinnamon was the best in summer. Anise oil $30 \%$ was intermediate 80.00 and $77.11 \%$ in winter and summer treatments respectively. In concern with the effect of the tested oils on brood rearing activity, Anise and Cinnamon oils at $30 \%$ concentration were the best (74.54 and $74.35 \%$. respectively) during January - February. However, in significant differences were found between the tested oils at 30\% concentration during August-September. Thymol was the best at $15 \%$ concentration ( 55.38\%).However, Cinnamon oil $30 \%$ was the best $(64.54 \%)$ followed by Thymol( $56.52 \%)$.
\end{abstract}

Keywords : Varroa destructor ,Apismellifera ,essential oils.

\section{INTRODUCTION}

Varroa destructor mite has become a serious pest of Apis mellifera all over the world ( Baker and Peng,1995; Rashid et al.,2014).It cause serious losses in apiculture of $A$. mellifera.It feeds on haemolymph of larvae, pupa and adult bees during all life (Anderson and Trueman, 2000). It also, decrease brood, colony ability to pollinate plants ( De Jong at al.,1984).V. destructor associated with the virus diseases, which six bee viruses were detected in bee infested by varroa( Shimanukiet al., 1994; and CorreaMarqueset al., 2003). Using of synthetics varroacides may due to increase of varroa resistance to these products (Thomsonetal., 2002). Recently, beekeepers have used some essential oils as well as volatile compounds to control varroa mites ( El-Shemy,1997 ; Allamet al.,2004;Sammataro et al., 2004 and Ruffinengeet al., 2007). Studies have shown that higher concentrations of formic acid can kill mites under capping (Calderon et al. 2000, Amrineet al. 2006). The present study aim to evaluate three essential oils i. e.Thymol, Cinnamon and Anise with two concentrations(15 and 30\%) in 
controlling applications compared to formic acid to controlling varroa mites in both capped brood and on adult bees in addition, the effects of these treatments on brood rearing.

\section{MATERIAS AND METHODS}

Present study was confirmed in an apiary selected at Ayash ElMehallaElKobra District, Gharbia Governorate in 2013 season. All colonies had brood nests composed of one standard deep and one shallow hive body. Each brood box contained 5 frames in winter season and 8 frames in summer season, had approximately equal numbers of bees, and had a laying queen.

\section{Evaluated materials}

Essential oils in two concentrations (15 and 30\%) were used in this study to management varroa mites comparing to Formic acid $65 \%$ given in Table (1). Colonies were divided into 7 groups, three colonies for each concentration as well as 3 colonies as a control (without treatment) .Three applications of each treatment were applied from 16 January to - February and from 15 August to - September , 2013.A completely randomized design was applied in this treatment.

\section{Table.1. Essential oils and their concentrations.}

\begin{tabular}{|c|c|c|}
\hline Serial No. & Name of acaricides & Concentrations \% \\
\hline 1 & Thymol & $15 \% \& 30 \%$ \\
\hline 2 & Anise oil & $15 \% \& 30 \%$ \\
\hline 3 & Cinnamon oil & $15 \% \& 30 \%$ \\
\hline 4 & Formic acid & $65 \%$ \\
\hline
\end{tabular}

\section{Application methods:}

1- The mixture of Essential oil Thymol or Anise and Cinnamon was prepared in two concentrations, 15 and $30 \%$ by mixing with olive oil (15ml: $85 \mathrm{ml}$ and $30 \mathrm{ml}: 70 \mathrm{ml}$, respectively). Talcum powder was added to each mixture at rate 1 oil: 2 powder) to make solid mix $(3 \times 3 \times 1 \mathrm{~cm})$ weighted $30 \mathrm{gm}$. .Each mixture was placed on the top of combs, changed every 10 days.

2- $120 \mathrm{ml}$ of $65 \%$ Formic acid was kept in a corked plastic bottle with cotton strip to regulate $4 \mathrm{~mL}$ evaporation / daily of Formic acid. The bottle was adjacent to an empty space above the brood.

\section{Assessment of bee infection}

For bees, pre-treatment count of mites was taken before application. About 100 adult bees/ colony were used to calculate varroa infestation using alcohol wash technique (De Jong et al., 1982), Post-treatment Assessment count of mites was taken after the end of each treatment application.

For brood, the mite infestation was evaluated by opening cells of sealing brood before treatment and mite infestation was assessed in inch ${ }^{2}$, three replicates / colony (Burgett and Burikam, 1985).

Efficacy of oils.

Effectiveness \% of the tested treatments were determined according to the formulae adopted by Liorente J-Martines(1989) as follow: 


\section{Effectiveness in controlling Varroa mites \%=}

Final of fallen mites in treatment-Final of fallen mites in control

Final of fallen mites in treatment

Whoever, on brood rearing activity, an area of $5 \times 5 \mathrm{~cm}$ in the middle of a worker comb (sealed brood) was selected after treatment to determine the effect of oils on brood rearing activity.

Effectiveness in brood rearing activity \%=

Final of increasing in treatment -Final of increasing in control $\times 100$

\section{Statistical analysis.}

Final of increasing in treatment

Randomized complete block design were applied to this experiment Mean mite mortality (fallen mites) and brood rearing activity were compared by analysis of variance technique to test the significance of data using the least significance test (LSD) at $5 \%$ probability level (Montgomery, 2001).Duncan analysis was used to compare between mean of fallen mites.

\section{RESULTS AND DISCCUSION}

Efficacy of some essential oils at different concentrations as well as Formic acid $65 \%$ was evaluated for controlling of varroa mites during the winter and summer seasons of 2013. Each treatment was applied three times from the first of January to the half of February and from the half of August to the half of September. Pre-treatment count of fallen mites was taken before treatment. The pre-count of the beginning of fallen mites was higher in summer than the winter season. It ranged from 21 to 29 infestation in winter and from 39 to 47 in summer.

Data in Table (2) revealed that from January to February, the fallen mites increased and the first application was the highest one. Thymol $30 \%$ showed the highest fallen mites (225 mites) at $1^{\text {st }}$ application, followed by 94 mites at the $2^{\text {nd }}$ application then 50 mites at the $3^{\text {rd }}$ application.. In case of Cinnamon 30\% recorded the second rank, it showed 103, 102 and 47 fallen mites, respectively. Anise oil $30 \%$ came in the $3^{\text {rd }}$ rank, the fallen mites were 155 mites at the $1^{\text {st }}$ application, 48 mites at the $2^{\text {nd }}$ application then 38 mites at the $3^{\text {rd }}$ application. Consequently, it could be ranking the essential oils according to the total fallen mites in descending order as follow, Thymol $30 \%$ (369 mites), Cinnamon oil 30\% (252 mites) then Anise oil 30\% ( 241 mites). In concentration 155 of the essential oils, Anise oil came in the first rank (205 mites) followed by thymol (175 mites) then cinnamon oil (142 mites). Formic acid $65 \%$ showed the highest total fallen mites (573 mites) compared to the tested essential oils. 
Table.2. Effectiveness of essential oils for controlling of Varroa mites during January - February, 2013.

\begin{tabular}{|c|c|c|c|c|c|c|}
\hline \multirow{2}{*}{ Treatment } & $\begin{array}{c}\text { Pre- } \\
\text { treatment } \\
\text { count }\end{array}$ & $\begin{array}{c}1^{\text {st }} \\
\text { Application }\end{array}$ & $\begin{array}{c}2^{\text {nd }} \\
\text { Application }\end{array}$ & $\begin{array}{c}3^{\text {rd }} \\
\text { Application }\end{array}$ & \multirow{2}{*}{$\begin{array}{l}\text { Total } \\
\text { fallen } \\
\text { mites }\end{array}$} & \multirow{2}{*}{ Efficacy \% } \\
\hline & $\begin{array}{l}\text { No. of } \\
\text { mites }\end{array}$ & $2 / 1-14 / 1$ & $15 / 1-26 / 1$ & $28 / 1-10 / 2$ & & \\
\hline Thymol 15\% & 23 & $82 e$ & $59 d$ & $34 d$ & 175 & 72.57 \\
\hline Anise oil $15 \%$ & 29 & 89de & $78 c$ & $38 d$ & 205 & 76.58 \\
\hline Cinnamon oil15\% & 24 & 61 & $37 e$ & $44 c$ & 142 & 66.19 \\
\hline \begin{tabular}{|l} 
Thymol $30 \%$ \\
\end{tabular} & 21 & $225 a$ & $94 b$ & $50 b$ & 369 & 86.99 \\
\hline Anise oil $30 \%$ & 25 & $155 b$ & 48de & $38 d$ & 241 & 80.00 \\
\hline Cinnamon oil $30 \%$ & 24 & $103 c d$ & $102 b$ & $47 \mathrm{bc}$ & 252 & 80.95 \\
\hline Formic acid $65 \%$ & 22 & $108 c$ & $223 a$ & $242 a$ & 573 & 91.62 \\
\hline Control & 21 & $16 f$ & $15 f$ & $17 \mathrm{e}$ & 48 & \\
\hline L.S.D at $5 \%$ & & 14.75 & 12.87 & 5.41 & & \\
\hline
\end{tabular}

Data in Table (3) revealed that the total fallen mites as a result to use the essential oils from August to September were more than those in from January to February, 2013. The total fallen mites due to the use of essential oils at $30 \%$ concentration were more than those at $15 \%$ concentration. On contrast of winter season, Cinnamon oil $30 \%$ showed the highest total fallen mites (684 mites) followed by Anise oil\% (533 mites), It could be noticed that Thymol $15 \%$ concentration was more effective (375mites) than the concentration 30\% (447 mites). Also, Formic acid 655 gave the highest fallen mites (976 mites) compared to the tested essential oils and it was more effective in summer season than the winter season.

Table.3. Effect of different essential oils for controlling the management of Varroa mites during August - September, 2013.

\begin{tabular}{|c|c|c|c|c|c|c|}
\hline \multirow[t]{2}{*}{ Treatment } & $\begin{array}{c}\text { Pre- } \\
\text { treatment } \\
\text { count }\end{array}$ & $\begin{array}{c}1 \text { st } \\
\text { Application }\end{array}$ & $\begin{array}{c}\text { 2nd } \\
\text { Application }\end{array}$ & $\begin{array}{l}3^{\text {rd }} \\
\text { Application }\end{array}$ & \multirow[t]{2}{*}{$\begin{array}{l}\text { Total } \\
\text { fallen } \\
\text { mites }\end{array}$} & \multirow[t]{2}{*}{ Efficacy \% } \\
\hline & No. of mites & $17 / 8-26 / 8$ & $27 / 8-6 / 9$ & $7 / 9-15 / 9$ & & \\
\hline Thymol 15\% & 43 & $291 a$ & $107 d$ & $49 d$ & 375 & 67.46 \\
\hline Anise oil 15\% & 37 & $112 c$ & $110 d$ & $48 d$ & 270 & 54.81 \\
\hline $\begin{array}{l}\text { Cinnamon } \\
\text { oil } 15 \%\end{array}$ & 39 & $147 \mathrm{~b}$ & $106 d$ & $35 d$ & 288 & 57.63 \\
\hline Thymol 30\% & 47 & $157 b$ & $157 c$ & $61 \mathrm{~cd}$ & 447 & 72.70 \\
\hline Anise oil 30\% & 41 & $293 a$ & $151 \mathrm{c}$ & $89 c$ & 533 & 77.11 \\
\hline $\begin{array}{l}\text { Cinnamon Oil } \\
30 \%\end{array}$ & 45 & $314 a$ & $257 b$ & $113 b$ & 684 & 82.16 \\
\hline $\begin{array}{l}\text { Formic acid } \\
65 \%\end{array}$ & 42 & $288 a$ & $320 a$ & $368 a$ & 976 & 87.50 \\
\hline Control & 38 & $28 \mathrm{e}$ & $33 e$ & $61 c$ & 122 & \\
\hline L.S.D at $5 \%$ & & 29.53 & 30.28 & 37.36 & & \\
\hline
\end{tabular}

The effectiveness of different essential oils for controlling varroa mites ranged between 66.19 to $86.99 \%$ in winter (January - February) and 54.81 to $82.16 \%$ in summer (August to September). In the period from January - February, Thymol oil $30 \%$ was the best $(86.99 \%$ followed by Cinnamon oil $30 \%(80.95 \%)$ then Anise oil 30\% ( $80.00 \%)$. However, the same oils at $15 \%$ were less effective. Floris, et al.(2004) stated that both Thymol formulations reduced significantly the levels of mite infestations of 
adult bees and sealed brood and its efficacy, expressed as percentage of mortality, was lower for both products (Apilife VAR 74.8 \pm 13.1 and $81.3 \pm$ 15.5, Apiguard $90.4 \pm 8.3$ and $95.5 \pm 8.7$ for sealed brood and adult bees, respectively).

On the other hand, treatments from August to September showed that Cinnamon oil 30\% was the best and occupied the first rank $(82.16 \%$ efficacy) in summer followed by Anise oil $30 \%(77.11 \%)$ then Thymol $30 \%$ $(67.46 \%)$. Similar results with different oils were suggested by Whittington et al (2000) examined the botanical oils neem, thymol, and canola control of parasitic mites (Varroa jacobsoni and Acarapiswoodi) in honey bee (Apis mellifera) colonies in British Columbia, Canada. Neem oil spray (5\% solution) killed $90 \pm 6 \%$ of varroa mites, 3 times more than that died in the untreated group. Thymol-oil spray ( $4.8 \mathrm{~g}$ Thymol/litre in $20 \%$ canola oil solution), thymol in vermiculite (3.6g/vermiculite block), and canola oil spray ( $20 \%$ solution) killed $79 \pm 8 \%, 68 \pm 6 \%$, and $65 \pm 6 \%$ of the varroa mites, respectively. Colonies treated with the Thymol-oil spray had a significantly lower tracheal mite infestation $(1.3 \pm 7.5 \%)$ at the end of the treatment period than the untreated group $(23.3 \pm 6.0 \%)$. All other treatments showed a slight but not statistically significant decrease in tracheal mite infestation levels. Also, Akyol and Yeninar(2008) reported that average efficacies of Thymovar and Bee Vital were found to be 96.91 and $88.66 \%$, respectively. El-Zemityet al.(2006) who found that clove oil gave good results in controlling varroa mites. Fouly and Al-Dehhairi (2009) stated that clove showed $62 \%$ efficacy in controlling varroa mites. Hussein et al.(2001) tested the 6 plants oils to control varroa mites and rated clove oil, the pest of among the other oils.

As far as the timing of application, the number of fallen mites was higher after the $1^{\text {st }}$ application than the $2^{\text {nd }}$ and $3^{\text {rd }}$ applications either in winter or summer treatments. These results are similar with other findings and treatments (Shoreit and Hussein,1994) who found that the maximum fallen mites was happen after the first treatment. Abdel Rahman and Rateb (2008) suggested that the mean number of fallen mites were higher after $24 \mathrm{~h}$., than after $48 \mathrm{~h}$ and after 72 which showed the lowest numbers. Also, Rashid et al.(2014) who stated that the mean number of fallen mites were higher after $24 \mathrm{~h}$ of treatment.

In case of Formic acid was more effective than the tested oils, which showed $91.62 \%$ in January to February and $87.50 \%$ in August to September. Also, the mean number of fallen varroamites increased gradually with timing application. The number of fallen mites was lower in the first treatment than the second and third treatment either in winter or summer application. Similar results were obtained by Rashid et al.(2011) who stated that formic acid significantly killed higher number mites compared to thymol . Also, Calderon et al. (2014) found that formic acid $86 \%$ gave effectiveness in controlling varroa mites $96.9 \%$, while Thymol released $94.7 \%$.

Effect of essential oils on brood rearing activity.

Data in Table (4) showed that both of Cinnamon and Anise oils treatments increased brood rearing activities percentage than Thymol in the two concentrations 15 and $30 \%$ compared to formic acid and the control 
treatments. No significant differences were found between Aniseoil, Cinnamon oil at $15 \%$ and Thymol at 30\% concentrations. Thymol oil $15 \%$ recorded the lowest increase in brood rearing (200.99 inch ${ }^{2}$ ) and efficacy\% $44.28 \%$. No significant differences were found between the Anise and Cinnamon at $30 \%$ concentration (439.99 and 436.65 inch $^{2}$ ). All the tested oils increased brood rearing compared to Formic acid( 297.99 inch $\left.^{2}\right)$ and control treatment (111.99 inch $\left.^{2}\right)$

Table.4. Effectiveness of essential oils on brood rearing activity during January - February, 2013.

\begin{tabular}{|l|c|c|c|c|c|}
\hline \multirow{2}{*}{ Treatment } & $\begin{array}{c}\text { 1st } \\
\text { Application }\end{array}$ & $\begin{array}{c}\mathbf{2}^{\text {nd }} \\
\text { Application }\end{array}$ & $\begin{array}{c}\text { 3rd } \\
\text { Application }\end{array}$ & $\begin{array}{c}\text { Brood } \\
\text { rearing } \\
\text { (Inch2) }\end{array}$ & Efficacy \% \\
\cline { 2 - 5 } & $\mathbf{2 / 1 - 1 4 / 1}$ & $\mathbf{1 5 / 1 - 2 6 / 1}$ & $\mathbf{2 8 / 1 - 1 0 / 2}$ & \\
\hline Thymol 15\% & 43 & 72.66 & 85.33 & $200.99 \mathrm{~d}$ & 44.28 \\
\hline Anise oil 15\% & 121.66 & 130.33 & 136.33 & $388.32 \mathrm{~b}$ & 71.16 \\
\hline Cinnamon oil 15\% & 121 & 138 & 160 & $385.88 \mathrm{~b}$ & 70.97 \\
\hline Thymol 30\% & 103.33 & 132.66 & 155.33 & $391.32 \mathrm{~b}$ & 71.38 \\
\hline Anise oil 30\% & 128.33 & 144.66 & 167 & $439.99 \mathrm{a}$ & 74.54 \\
\hline Cinnamon oil 30\% & 131.66 & 145.66 & 159.33 & $436.65 \mathrm{a}$ & 74.35 \\
\hline Formic acid 65\% & 98.33 & 110 & 89.66 & $297.99 \mathrm{c}$ & 62.41 \\
\hline Control & 36.66 & 37 & 38.33 & $111.99 \mathrm{e}$ & \\
\hline L.S.D at 5\% & & & & 41.28 & \\
\hline
\end{tabular}

Data in Table (5) showed contrast results during January - February, Out of concentration $15 \%$, Thymol $15 \%$ ranked the first in increasing brood rearing activity(55.38\%).However, Cinnamon oil $30 \%$ and Thymol 30 and 15 $\%$ were the best 64.54 , and $56.32 \%$, respectively. It could be noticed that Formic acid showed lower efficiency in summer $(40.18 \%)$ than those in summer months (62.41\%) compared the control treatment. No significant differences were found between the tested oils at 30\% concentration.

Table.5. Effectiveness of essential oils on brood rearing activity during August - September, 2013.

\begin{tabular}{|l|c|c|c|c|c|}
\hline \multicolumn{1}{|c|}{ Treatment } & $\begin{array}{c}\mathbf{1}^{\text {st }} \\
\text { Application }\end{array}$ & $\begin{array}{c}\mathbf{2}^{\text {nd }} \\
\text { Application }\end{array}$ & $\begin{array}{c}\mathbf{3}^{\text {rd }} \\
\text { Application }\end{array}$ & $\begin{array}{c}\text { Brood } \\
\text { rearing } \\
\text { Inch }^{2}\end{array}$ & Efficacy\% \\
\cline { 2 - 6 } $\mathbf{2 / 1 - 1 4 / 1}$ & $\mathbf{1 5 / 1 - 2 6 / 1}$ & $\mathbf{2 8 / 1 - 1 0 / 2}$ & \\
\hline Thymol 15\% & 148.33 & 181 & 203.33 & $532.66 \mathrm{~b}$ & 55.38 \\
\hline Anise oil 15\% & 81.66 & 100.66 & 117.33 & $299.65 \mathrm{f}$ & 20.68 \\
\hline $\begin{array}{l}\text { Cinnamon oil } \\
15 \%\end{array}$ & 110 & 116.33 & 132.33 & $358.66 \mathrm{e}$ & 33.73 \\
\hline Thymol 30\% & 166.66 & 182.66 & 197.33 & $546.65 \mathrm{~b}$ & 56.52 \\
\hline Anise oil 30\% & 146.66 & 168 & 126 & $440.66 \mathrm{c}$ & 46.06 \\
\hline $\begin{array}{l}\text { Cinnamon oil } \\
30 \%\end{array}$ & 193.33 & 220 & 257 & $670.33 \mathrm{a}$ & 64.54 \\
\hline $\begin{array}{l}\text { Formic acid } \\
65 \%\end{array}$ & 126 & 141 & 130.33 & $397.33 \mathrm{~d}$ & 40.18 \\
\hline Control & 133.33 & 131 & 123.33 & $237.66 \mathrm{~d}$ & \\
\hline L.S.D at 5\% & & & & 28.72 & \\
\hline
\end{tabular}




\section{REFERENCES}

AbdELrahman, M.F. and Rateb, S.H., (2008). Evaluation of lemon juice for controlling Varroa destructor in honeybee colonies.Assiut J. Agric. Sci., 2: 195-206.

Akyol E. and Yeninar H. (2008).Controlling Varroa destructor (Acari: varroidae) in honeybee Apismelifera (hymenopetra :Apidae) colonies by using Thymovar and Beevital. Italy J. Anim. Sci.7: $237-242$.

Allam, S. F., Hassan, M. F, Rizk, M. A and Zaki, A. U.( 2004). Essential oils via feeding syrups for hybrid of Apismelliferacarnicato control varroa mite Varroa destructor through biological aspects on drone brood during spring. Minufiya J. Agricultural Research.29(6): 14131424.

Amrine, J.W., R.Noel, and Delia.(2006) .Foemicacidfumigator for controlling honey bee mites in bee hive-Int.J.Acarol. 32:115-124.

Anderson, D. L. and Trueman, J. W. H.( 2000). Varroajacobsoni(Acari: Varroidae) is more than one species. Exp. Appl. Acar. 24: 165189.

Baker, M. D. and Peng C. Y. S. (1995).Varroajacobsoniand Tropilaelapsclareae: A perspective of life history and why Asian bee mites preferred European honeybees. American Bee J. 135(6): 415420.

Burgett,D.M.andBurikam,I.,(1985).Number of adult honeybees (Hymenoptera:Apidae ) occupying a com:A standard for estimating colony populations.J.econ. Ent.,78:1154-11556

Calderon, R. A., R. A. Ortiz, H. G. Arce, J. W. van Veen, and J. Quan. (2000). Effectiveness of formic acid on varroamortality in capped brood cells of Africanized honey bees. J. Apic. Res. 39: 177-179.

Calderon,R.A.,Ramirez.M.;Ramirez.F. andVillalobos.E. (2014). Effectiveness of formic acid and thymol in the control of Varroa destructor in Africanized honey bee colonies .AgroonCostarricenseVol. 38 .n.1,pp.175- 188 Issn 0377-9424

Correa -Marques, M.H. ,L. M.Medina ,S.J.Martin and D.DeJong,( 2003).Comparing data on the reproduction of Varroa destructor , Gente. Mol.Res., 2:1-6.

De Jong, D., Goncalves, L. S. and Morse, R. A. (1984).Dependence on climate of the virulence of Varroajacobsoni.Bee World.65: 117-121.

DeJong,D.D.De Andre Roma, and L.S.Goncalves(1982). .Acomparative analysis of shaking solutions for the getection of varroajacobsni on adult honey bees .Apicultural Research 21:165-167.

El-Shemy, A. A. M. (1997).Potential methods of controlling varroa mite VarroajacobsoniOud.Without chemicals.J. Agri. Sci. Mansoura,(4)643-653.

EL-Zemity, S., Rezk, R.H.A. and Zaitoon, A.A.,( 2006). Acaricidal activity of some essential oils and their monoterpenoidal constituents against the parasitic bee mites, Varroa destructor (Acari: Varroidae). J. appl. Sci. Res, 2: 1032-1036. 
Fouly, A.H. and AL-Dehhairi, M.A., (2009). Evaluation of infestation levels of the ectoparasitic mite Varroa destructor infesting honeybee Apismelliferaand its control using essential oil in Qassim Region, Saudi Arabia. J. Ent, 6:135-144.

Floris, I, Satta, A,Cabras , P , Garau, V L. , andAngioni A (2004).Comparison Between Two Thymol Formulations in the Control of Varroa destructor:Effectiveness, Persistence, and Residues.Journal of Economic Entomology 97(2):187-191.

Hussein, M.H., Ali, A.M., Morsi, M.A. and Rateb, S.H., (2001). Using of some plant oils for controlling of some parasites, diseases and pests of honeybee colonies in Assiut region, Egypt. Safe Alternatives of Pesticides for Pest Management Conference, Assiut Univ., Egypt,pp. 349-355.

Montgomery, D.C( 2001). Design and analysis of experiments. $5^{\text {th }}$ Ed John Willy and Sons, New York pp. 64-65.

Rashid, M., Wagghoure, E.S., Raja, S., Sarwar, G.andAslam, M., (2011). Effect of thymol and formic acid against ectoparasitic brood mite Tropilaelapsclareae in Apismellifera colonies.Pakistan J.Zool.,43:9195.

Rashid, M.,Saima ,A.; Snaizia.AR.;Atta UL-Moshin,E.S.W.Ghulan,S.;Noor,I.; and Wagar,A.(2014).Control Varroa destructor( Acari;varroidae ) in Apismellifera Hymenoptera : Apidae) by using plant oil extract . Pakistan J .Zool ., Vol 46( 3) , PP609 -615.

Ruffinengo, S. R., Maggi, M. C., Faverin, S. B., Garci de la Rosa, C. P. Bailac, J. P. and Eguaras, M. (2007). Essential oils toxicity related to Varroa destructor under laboratory conditions. ZootecniaTropica.

Sammataro, D., Degrandi-Hoffman, G., Ostiguy, N., Wardell, G. and Finley, J.( 2004). Testing a combination of control strategies to manage Varroa destructor (Acari: Varroidae) population levels in honeybee (Hymenoptera: Apidae) colonies. International J. Acarology. 30: 7176.

Shoreit, M.N. and Hussein, M.H., (1994). Field trials for the control of varroa disease of honeybees by using coriander seeds extract. Zagazig J. agric. Res., 21: 279288.

Liorente J .Martinez (1989).Trialsof effectiveness of valuvalinate (Apistan ) against varrotosis of honey bee sealed brood being present Cuadernos de Apiculture, 6: 14-16.

Shimanuki,H.Calderone ,N.W.and Knox, A.D.(1994). Parasitic mite syndrome: the symptoms Am. Bee J 134: 827 -829 .

Thompson, H. M., Brown, M. A., Ball, R. F. and Bew, M. H. (2002).First report of Varroa destructor resistance to pyrethroids in the UK.A pp 357366.

Whittington, R.; Winston, M. L.; Melathopoulos, A. P.; Higo, H. A.(2000) Evaluation of the botanical oils neem, thymol, and canola sprayed to control VarroajacobsoniOud. (Acari: Varroidae) and Acarapiswoodi (Acari: Tarsonemidae) in colonies of honey bees (Apismellifera L., Hymenoptera: Apidae). American Bee Journal, Vol. 140 (7) : 567572. 
تقييم بعض الزيوت العطريـة لمكافحة اكـاروس الفـاروا وتأثيرهـا على نشـاط تربية

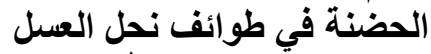

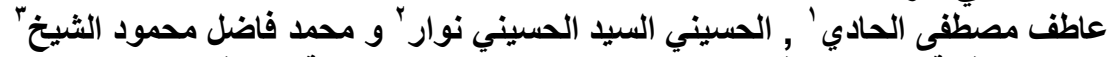

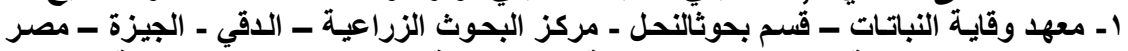

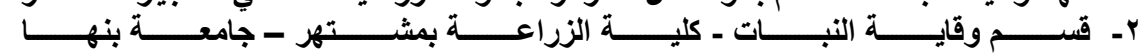

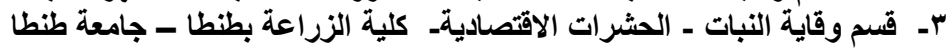

أجريت هذه الدراسـة لتقيبم بعض مركبـات الزيوت العطريـة لمكافحـة اكساروس الفاروا

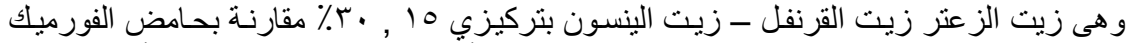

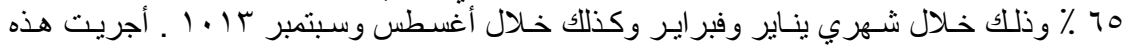

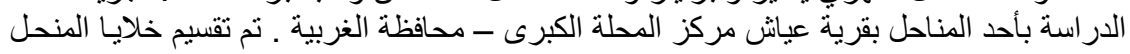

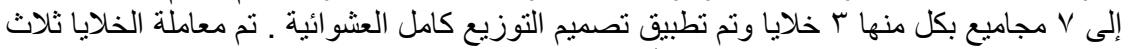

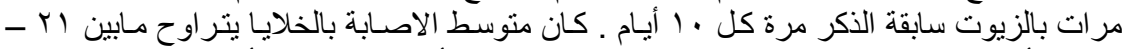

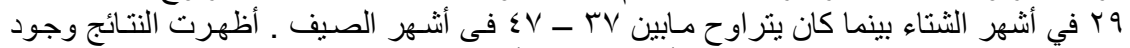

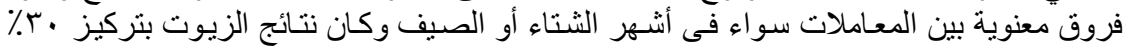

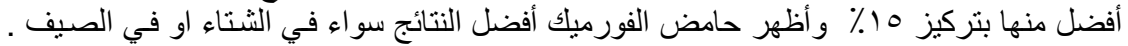

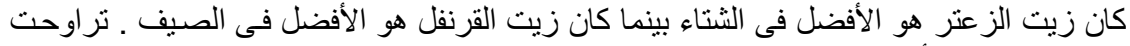

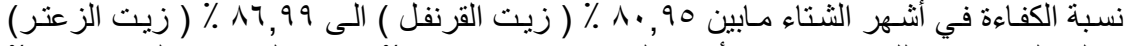

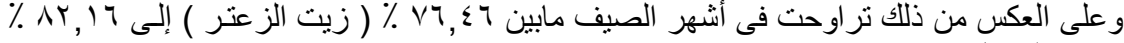

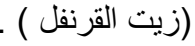

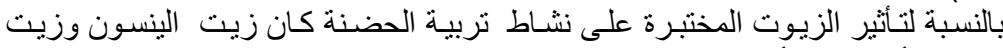

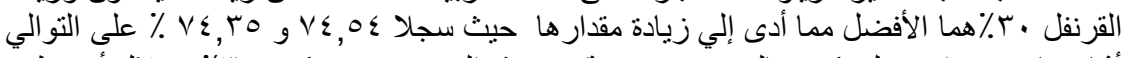

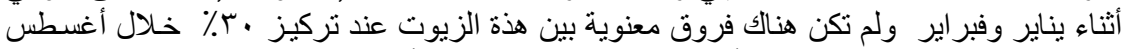

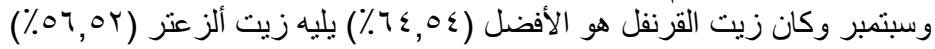

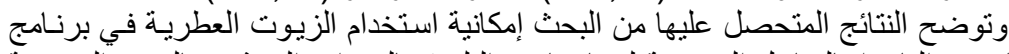

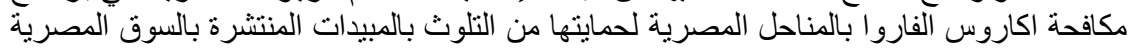

